\title{
The Influence of Madrasah Leadership and the Role of the Committee to the Efficiency and Effectiveness of School Operational Assistance Funds (BOS) In Madrasah Tsanawiya (MTs) Public School in Semarang City
}

\author{
Onisimus Amtu \\ IAKN Ambon, Indonesia
}

Nerru Pranuta Murnaka

STKIP Surya Tangerang, Indonesia

Nur Rohman

Universitas Islam Nahdlatul Ulama Jepara, Indonesia

Eni Sumarni

SMP Negeri 1 Bengkayang, Indonesia

DOI: 10.31364/SCIRJ/v6.i10.2018.P1018575

http://dx.doi.org/10.31364/SCIRJ/v6.i10.2018.P1018575

\begin{abstract}
One of the forms of education funded by the Indonesian government to the public is the BOS Fund. Therefore, in the process of utilization in demand accountability, transparent, efficiency, and effective. In the process of management / utilization of these funds can not be separated from the role of school principals and school committees. This study aims to: 1) To know the magnitude of the influence of the role of madrasah heads to the efficient and effectiveness of the management of boss funds; 2) To know how the role of School Committee as Supporting and Controlling Agency in managing BOS Fund in MTs Public School in Semarang City. This research is a quantitative research. This research was conducted in all MTs Public School in Semarang City which amounted to 2 schools namely MTs Public School 1 Semarang City, and MTs Public School 2 Semarang City. The population of this study are all teachers, staff, and committees in MTs Public School in Semarang City. Intake of random sampling using table Krejcie \& Morgan. Data collection techniques used in this study is a questionnaire. The results of this study indicate that there is a positive influence of madrasah head leadership on the management of BOS funds. Contribution of $38.7 \%$ to the management of BOS funds. In addition to MTs Public School 1 the role of the committee in providing support in the management of BOS funds amounted to 54.17\%, while in MTs Public School 2 of 57.14\%, For the role of the committee as Controlling in the management of BOS MTs Public School 1 of $59.30 \%$, and MTs Public School 2 amounted to $57.14 \%$.
\end{abstract}

Keywords: Madrasah Leadership, School Committee, management of BOS, efficiency, and effective.

\section{INTRODUCTION}

Changes in the political, social, society, and economic systems that were the result of the transition of the New Order government to the reform-order government led to the increasing public demand for good governance. One form of good governance that is the principle of accountability in every community and government activities both in the central and regional, one of them in the public sector. The realization of accountability and transparency are the main objectives of public sector reform. Accountability is a form of government accountability, both in the central government and local government to the public. In addition to accountability, transparency is also important. Transparency is the provision of information to the public based on the fulfillment of public rights (Stanbury, 2003). According to the Law of the Republic of Indonesia (RI) Number 25 Year 2009 on public service states that education is one of the public services.

Educational Accountability according to Gorton (1991) is a responsibility (school or educational institution) in the achievement of educational goals. So it can be said that educational accountability is a willingness to give information to the parties who have the 
right and authority to ask it. The authorities such as head of department, mayor, BPKP, BPK, and stakeholder. The goal of school accountability is to assess school performance and public satisfaction of education services organized by schools, to engage the public in the supervision of educational services and to account for the commitment of educational services to the public. Accountability in the management of school education financing means the use / use of tuition must be accountable in accordance with the established planning. The accountability of the use / use of school fees is intended to determine the efficiency and effectiveness of the use of money.

School Operational Assistance Fund (BOS) is a fund provided by the central government and local governments for funding the cost of education units (Minister of National Education Regulation No. 69 of 2009). So that all levels of society to be able to enjoy free education for basic education level. But what happens in the field of misappropriation of BOS funds. According to the Indonesian Corruption Watch (ICW) study, nationally with a sample of 3,237 schools in 33 provinces, the value of BOS funds was found to be around Rp 28 billion. The average per-formance of each school was Rp 13.6 million and occurred in 2,054 or 63.5 percent of the total sample of the schools being audited (Fauzan, 2014). This condition occurs because there is still a lack of transparency and accountability in the management of School Operational Assistance (BOS) funds. In Act No. 20 of 2003 Article 48 states that "principle of fund management education based on the principle of participation, transparency, public accountability, efficiency and equity .

The management of BOS funds can not be separated from the role of principal in managing, allocation of funding for school operations. A professional school principal is required to have the ability to manage school finances, whether planning, implementing, or evaluating and accountability (Mulyasa, 2006). Sa'ud and Makmun (2009) states that planning is the process of preparing various decisions that will be implemented in the future to achieve the goals that have been determined. This indicates that the principal's ability to plan finance for an activity plan along with other support resources available at school is something very important. The problem of managing BOS funds in schools is often not according to the rules of play because principals dominate policy. Especially in preparing the program and budget allocation. In fact, structurally, there are people who are tasked with handling it. The dominance of the principal of bias makes the process of making accountability reports of BOS funds difficult to do according to the mechanism. In addition, the orderly administration of the use of BOS funds is also a constraint of its own. It still needs improvement.

One indicator of transparency of BOS funds management is existence School Committee. According to Mulyasa (2011: 127) the school committee is an independent body which accommodate the participation of the community in order to improve the quality, equity and efficiency of education management in schools. According to Law Number 20 Year 2003 regarding National Education System Article 56 paragraph 3 states that the school committee as an independent institution is formed and plays a role in improving the quality of service by providing consideration, direction and support of personnel, facilities and infrastructure, and educational supervision on education level.

School committees are established from school stakeholders, ie teachers and parents. However, in reality many parents do not know the existence and function of the school committee. The ignorance was the deliberate intent of the school principal and other school officials who feared the policy controls that the committee would undertake. The management of BOS funds should be done transparently by involving the School Committee. Based on Kepmendiknas Number 044 / U / 2002, the school committee has four main roles in carrying out its duties, namely: 1) Advisory Agency; 2) Supporting (supporting agency); 3) Controller (controlling agency); 4) Mediator between government (executive). It is intended that there is an effective and efficient control mechanism in the utilization of these funds. In this study, researchers only see the role of the committee as a supporting aspect (supporting agency) and controller (controlling agency).

Madrasah Tsanawiyah (MTs) is one of the educational providers for secondary school (Law No. 20 of 2003). MTs is an equal educational institution with a junior high school that has Islamic characteristics that are managed and developed under the auspices of the Ministry of Religious Affairs of the Republic of Indonesia. Like SMP / SMPLB, MTs also get BOS funds. Based on this background, the purpose of this study is 1) To know the magnitude of the influence of the role of madrasah heads to the efficient and effectiveness of the management of boss funds; 2) To know how the role of School Committee as a Supporter (support agency) in the management of BOS funds in MTs Public School in Semarang City; 3) To know how School Committee's role as a controller in managing BOS funds in MTs Public School in Semarang City ?; 4) To know how the role of School Committee as Controlling (agency control) in managing BOS funds in MTs Public School in Semarang City?

\section{RESEARCH METHODS}

The research method used in this research is quantitative research method. B. This research was conducted in all MTs Public School in Semarang City which amounted to 2 schools namely MTs Public School 1 Semarang City, and MTs Public School 2 
Semarang City. This research was conducted in December 2017 until January 2018. The population of this research is all teachers, staff, and committee in MTs Public School in Semarang City.

Table 1. Data Number of Teachers, Staff, and School Committees

In MTs Public School in Semarang City.

\begin{tabular}{|c|c|c|c|c|}
\hline \multirow{2}{*}{ Amount } & \multicolumn{4}{|c|}{ Amount } \\
\cline { 2 - 5 } & \multirow{2}{*}{ Committee } & Teacher & Sdaff & Amount \\
\cline { 2 - 5 } & & 40 & 11 & 51 \\
\hline $\begin{array}{c}\text { Mts Public } \\
\text { School 1 }\end{array}$ & 11 & 55 & 11 & 66 \\
\hline $\begin{array}{c}\text { Mts Public } \\
\text { School 2 }\end{array}$ & 12 & & & \\
\hline
\end{tabular}

Data collection techniques used in this study is a questionnaire. Instrument Research The instrument used in this study is a questionnaire. The system used is a scoring based on Likert scale. In this study Likert scale is used to facilitate the respondents in answering questions, then respondents answer questions in accordance with the existing code in the questionnaire expected data obtained valid and has accuracy in accordance with the expectations of the research as well as get information in the form of management of BOS funds in MTs Public School in Semarang city.

\section{DATA ANALYSIS}

This research was conducted in MTs Public School in Semarang, that are MTs Public School 1 Semarang, and MTs Public School 2 Semarang. The data retrieval process in this study was conducted from December 2017 to January 2018.

a) Leadership of Madrasah Principals on the management of BOS funds

In this study, samples taken to determine the influence of madrasah head leadership on the management of boss funds, from MTs Public School 1 Semarang taken 35 people as a sample consisting of 28 teachers and 7 staff / education personnel. Medium of MTs Public School 2 Semarang taken 40 people as a sample consisting of 34 teachers and 6 staff / education staff. Because the data collected is ordinal, then a regression test, the data is converted first with the interval successive method (MSI) to be the interval data.

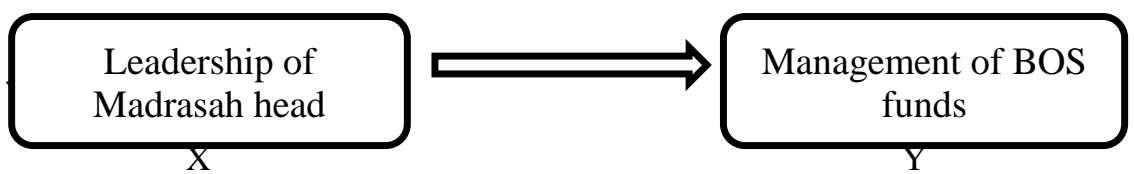

Leadership of Madrasah principal becomes independent variable $=X$.

Boss fund management becomes dependent variable $=Y$.

The data already obtained tested the normality and linearity. The following is data of normality test results of principal leadership $(\mathrm{X})$ and boss fund management (Y).

Table 2 One-Sample Kolmogorov-Smirnov Test

\begin{tabular}{|l|l|c|c|}
\hline \multicolumn{2}{|l|}{} & $\begin{array}{c}\text { Leadership of } \\
\text { Mts'head (X) }\end{array}$ & $\begin{array}{c}\text { Management of } \\
\text { BOS funds(Y) }\end{array}$ \\
\hline N & & 75 & 75 \\
\hline Normal Parameters & Mean & 82,6940 & 93,6866 \\
\hline & Std. Deviation & 3.61442 & 3.11021 \\
\hline Most Extreme Differences & Absolute & .264 & .250 \\
\hline & Positive & .264 & .186 \\
\hline & Negative & -.183 & -.250 \\
\hline Kolmogorov-Smirnov Z & & 1.628 & 1.558 \\
\hline Asymp. Sig. (2-tailed) & & .166 & .075 \\
\hline
\end{tabular}


a. Test distribution is Normal.

b. Calculated from data.

H0: The sample data used is from a normally distributed population

Ha: The sample data used is from an abnormally distributed population

In Table 2 we get the sig value. in leadership variable of head of madrasah is $0,166=16,6 \%>5 \%$ so Ho is accepted, while for variable of management of BOS fund $(\mathrm{Y})$ obtained by sig value. $=0.075=7.5 \%>5 \%$ so Ho is accepted. So it can be concluded that the data of both research variables come from the normal distributed population. Prior to the linear regression test, prerequisite test is tested linearity test. Test linearity, which aims to ensure the relationship between independent variables and dependent variables are linear, quadratic or in a higher degree. The guidelines for viewing this kelinieritasan is can be seen from the value of Sig. (probability), if the probability value $<0.05$ then the data linear. The following is the data of linearity test results.

Table 3. Test of Principal Leadership Linieritas Against the Management of BOS Funds

ANOVA Table

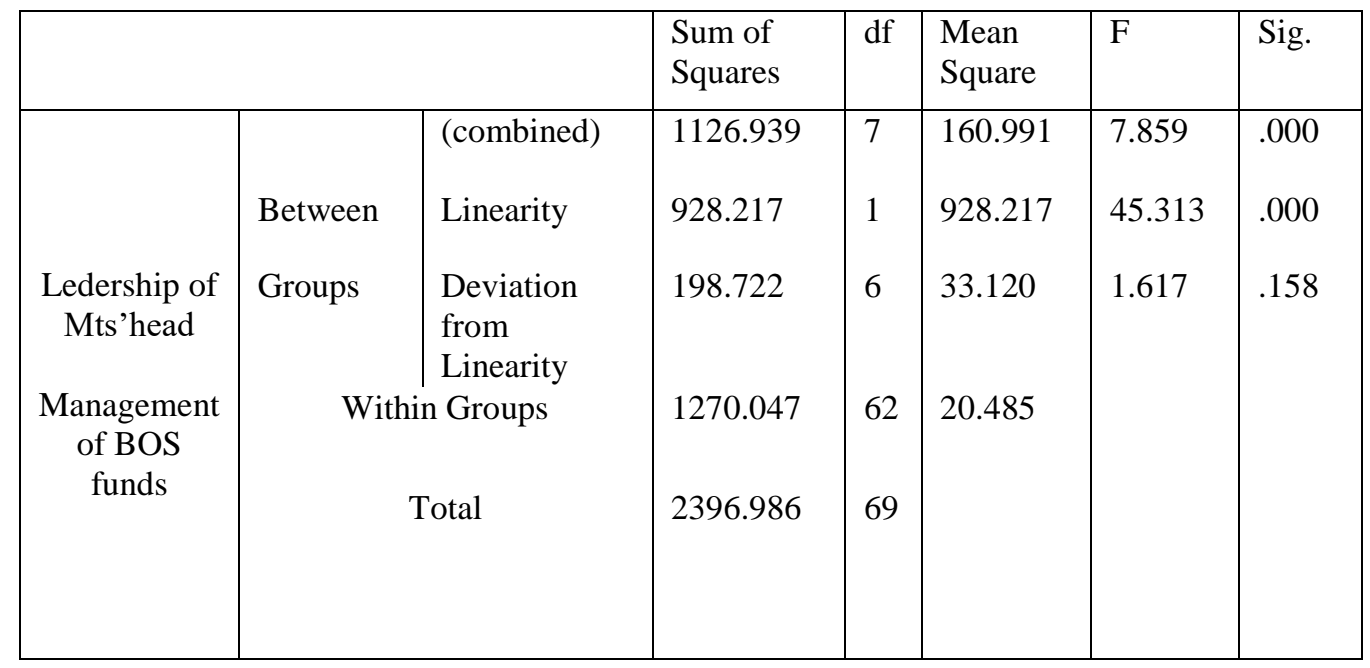

H0: There is no linear relationship between Leadership variables Madrasah Head (X) with Fund Management Boss (Y)

Ha: There is a linear relationship between variables Leadership Principal (X) with Fund Management Boss (Y)

In the table seen from the Linearity row, the significance value is less than $0.05(0.036<0.05)$ so Ha is accepted. This means that the relationship between headmaster leadership variable and boss fund management variable is linear. Because the prerequisite test of normality and linearity has been fulfilled, then for the next step is ui linear regression. Linear regression test aims to determine the relationship between variables

Table 4. Linier Regression Test Leadership Leadership Against the Management of BOS Funds

Coefficients ${ }^{\mathrm{a}}$

\begin{tabular}{|c|c|c|c|c|c|}
\hline \multirow{2}{*}{ Model } & \multicolumn{2}{|c|}{$\begin{array}{c}\text { Unstandardized } \\
\text { Coefficients }\end{array}$} & $\begin{array}{c}\text { Standardized } \\
\text { Coefficients }\end{array}$ & \multirow{2}{*}{$\mathrm{t}$} & Sig. \\
\cline { 2 - 5 } & $\mathrm{B}$ & Std. Error & Beta & \\
\hline $\begin{array}{l}\text { (Constant) } \\
\text { Management of BOS } \\
\text { funds }\end{array}$ & .253 & 22.620 & & -.011 & .991 \\
& .944 & .144 & .622 & 6.555 & .000 \\
\hline
\end{tabular}

a. Dependent Variable: Principal Leadership

H0: There is no influence between variables Leadership Head of Madrasah (X) with Fund Management Boss (Y)

Ha: There is influence between variables Leadership Head of Madrasah (X) with Fund Management Boss (Y) 
In Table 4 we get the sig value. on the variable in the management of the boss funds amounted to $0.000=0.00 \%<5 \%$ so that Ha accepted. This means that there is influence of Madrasah principal leadership on the management of BOS funds.

Table 5. Coefficient of Determination

Model Summary

\begin{tabular}{|l|c|r|r|r|}
\hline Model & R & R Square & $\begin{array}{c}\text { Adjusted R } \\
\text { Square }\end{array}$ & $\begin{array}{c}\text { Std. Error of the } \\
\text { Estimate }\end{array}$ \\
\hline 1 & $.622^{\mathrm{a}}$ & .387 & .378 & $\mathbf{4 . 6 4 7 5 3}$ \\
\hline
\end{tabular}

a. Predictors : (constant), Management of BOS funds

The leadership of the Madrasah principal (X1) with the management of BOS funds, proves that there is a positive influence, where the correlation coefficient obtained is rxy $=0.622$ with the determinant coefficient is $r 2=0.387$. This means that the leadership of madrasah heads contributes $38.7 \%$ to the management of BOS funds, and the regression equation is $\mathrm{Y}=0.253+$ $0.944 \mathrm{X} 1$. This regression equation explains that there is a positive influence which if the scores also rise.

b) The role of the Committee on the management of BOS funds

The data used to determine the role of school committees in managing BOS funds in MTs School in this study obtained through the instrument in the form of a questionnaire, the number of questionnaires is 21 points. This study consists of two roles of school committees: 1) The role of school committees as supporting bodies in the management of BOS funds; 2) The role of the school committee as a controlling agency in the management of BOS funds. Each school committee role in this research is expressed through indicators such as boss decision-making mechanism, boss fund utilization mechanism and school accountability.

a) Role of School Committee as Supporting in Management of BOS Fund in Madrasah Tsanawiya (MTs) Public School in Semarang City.

Based on Depdiknas (2003) role of School Committee as supporting (one supporting agency) function for budget management. In this research is assessed based on BOS fund raising mechanism, BOS fund utilization mechanism and school accountability to BOS funds. The following provides empirical data on the role of school committees as supporting bodies in the management of BOS funds in MTs Public School 1 Semarang per indicator.

Table 6. Recapitulation of School Committees' Roles as Supporting In BOS Funds Management Mechanism in MTs Public School 1 Semarang

\begin{tabular}{|c|c|c|c|c|}
\hline Aspect & $\begin{array}{l}\mathrm{A} \\
\%\end{array}$ & $\begin{array}{l}\mathrm{O} \\
\%\end{array}$ & $\begin{array}{l}\mathrm{S} \\
\%\end{array}$ & $\begin{array}{l}\mathrm{N} \\
\%\end{array}$ \\
\hline BOS funds raising mechanism & $62.50 \%$ & $37.50 \%$ & $0.00 \%$ & $0.00 \%$ \\
\hline Mechanism of using BOS funds & $50.00 \%$ & $50.00 \%$ & $0.00 \%$ & $0.00 \%$ \\
\hline Accountability of school to BOS funds & $50.00 \%$ & $37.50 \%$ & $12.50 \%$ & $0.00 \%$ \\
\hline Average & $54.17 \%$ & $41.67 \%$ & $4.17 \%$ & $0.00 \%$ \\
\hline
\end{tabular}

Description : A = Always, $\mathrm{O}=$ Often, $\mathrm{S}=$ Sometime, $\mathrm{N}=$ Never

Through the data above Table 6 can be seen in the role of the committee as a consideration in the management of BOS funds in MTs Public School 1 Semarang, a high role of 54.17\%, and low role of $4.17 \%$. The results show that most school committees play a high role, while the school committees with moderate and low roles are only a small fraction.

Table 7. Recapitulation of School Committee Roles as supporting In BOS Funds Management Mechanism at MTs Public School 2 Semarang

\begin{tabular}{|c|c|c|c|c|}
\hline \multirow{2}{*}{ Aspect } & $\mathrm{A}$ & $\mathrm{O}$ & $\mathrm{S}$ & $\mathrm{N}$ \\
& $\%$ & $\%$ & $\%$ & $\%$ \\
\hline
\end{tabular}




\begin{tabular}{|c|c|c|c|c|}
\hline BOS funds raising mechanism & $42.86 \%$ & $57.14 \%$ & $0.00 \%$ & $0.00 \%$ \\
\hline Mechanism of using BOS funds & $71.43 \%$ & $28.57 \%$ & $0.00 \%$ & $0.00 \%$ \\
\hline $\begin{array}{c}\text { Accountability of school to BOS } \\
\text { funds }\end{array}$ & $57.14 \%$ & $28.57 \%$ & $14.29 \%$ & $0.00 \%$ \\
\hline Average & $57.14 \%$ & $38.10 \%$ & $4.76 \%$ & $0.00 \%$ \\
\hline
\end{tabular}

Description : A = Always, $\mathrm{O}=$ Often, $\mathrm{S}=$ Sometime, $\mathrm{N}=$ Never

Through the data above Table 7 can be seen in the role of the committee as a consideration in the management of BOS funds in MTs Public School 2 Semarang, a high role of 57.14\%, and the low role of $4.76 \%$. The results show that most school committees play a high role, while the school committees with moderate and low roles are only a small fraction.

b) School Committee's Role as Controlling in BOS Fund Management at MTs Public School in Semarang City

Table 8. The Role of School Committees as Controllers In Mechanism of BOS Fund Usage at MTs Public School Semarang

\begin{tabular}{|l|c|c|c|c|}
\hline \multicolumn{1}{|c|}{ Aspect } & $\begin{array}{c}\mathrm{A} \\
\%\end{array}$ & $\begin{array}{c}\mathrm{O} \\
\%\end{array}$ & $\begin{array}{c}\mathrm{S} \\
\%\end{array}$ & $\begin{array}{c}\mathrm{N} \\
\%\end{array}$ \\
\hline BOS funds raising mechanism & $71.88 \%$ & $28.13 \%$ & $0.00 \%$ & $0.00 \%$ \\
\hline Mechanism of using BOS funds & $70.31 \%$ & $29.69 \%$ & $0.00 \%$ & $0.00 \%$ \\
\hline $\begin{array}{l}\text { Accountability of school to BOS } \\
\text { funds }\end{array}$ & $35.71 \%$ & $46.43 \%$ & $17.86 \%$ & $0.00 \%$ \\
\hline
\end{tabular}

Description : A = Always, $\mathrm{O}=$ Often, $\mathrm{S}=$ Sometime, $\mathrm{N}=$ Never

Table 9. The Role of School Committees as Controllers In Mechanism of BOS Fund Usage in MTs Public School 2 Semarang

\begin{tabular}{|c|c|c|c|c|}
\hline Aspect & $\begin{array}{c}\mathrm{A} \\
\%\end{array}$ & $\begin{array}{c}\mathrm{O} \\
\%\end{array}$ & $\begin{array}{c}\mathrm{S} \\
\%\end{array}$ & $\begin{array}{c}\mathrm{N} \\
\text { BOS funds raising mechanism }\end{array}$ \\
\hline $\begin{array}{l}\text { B } \\
\text { Mechanism of using BOS funds }\end{array}$ & $57.14 \%$ & $42.86 \%$ & $14.29 \%$ & $0.00 \%$ \\
\hline $\begin{array}{l}\text { Accountability of school to } \\
\text { BOS funds }\end{array}$ & $57.14 \%$ & $28.57 \%$ & $14.29 \%$ & $0.00 \%$ \\
\hline \multicolumn{1}{|c|}{ Average } & $57.14 \%$ & $38.10 \%$ & $9.52 \%$ & $0.00 \%$ \\
\hline
\end{tabular}

Description : $\mathrm{A}=$ Always, $\mathrm{O}=$ Often, $\mathrm{S}=$ Sometime, $\mathrm{N}=$ Never

Through the above data Table 8 can be seen in the role of the committee as Controlling in the management of BOS funds in MTs Public School 1 Semarang, a high role of $59.30 \%$, and the low role of 5.95\%. The results show that most school committees play a high role, while the school committees with moderate and low roles are only a small fraction. Through the data above Table 9 can be seen in the role of the committee as Controlling in the management of BOS funds in MTs Pulic School 2 Semarang, a high role of $57.14 \%$, and the low role of $9.52 \%$. The results show that most school committees play a high role, while the school committees with moderate and low roles are only a small fraction. 
c). Efficiency and Effectiveness of BOS Fund Management in

Madrasah Tsanawiya (MTs) Public School in Semarang City.

The effectiveness criteria for BOS are as follows:

1). It is said to be Effective when:

Use of BOS per post $\leq$ Maximum Percentage

2). Said Not Effective when:

Use of BOS per post> Maximum Percentage

Shopping Efficiency Ratio

To find out the level of efficiency of BOS funds allocation realization, the formula used is as follows:

Percentage Efficiency $=($ Actual Expenditure $) /$ Budget $\times 100 \%$

The following is one BOS funds report in one period.

Table 10. Recap BOS Report MTs Public School 1 Semarang (In one Period)

\begin{tabular}{|l|c|c|c|c|}
\hline & Period 1 & \% Limit Use & $\begin{array}{c}\text { Limit } \\
\text { Use }\end{array}$ & Effectiveness \\
\hline Receipts & 46.950 .000 & & & \\
\hline Spending & & & & Effective \\
\hline Honorarium & 3.700 .000 & $10 \%$ & 4.685 .000 & Effective \\
\hline Office Stationery & 6.400 .000 & $15 \%$ & 7.042 .500 & Effective \\
\hline Materials Display & 8.600 .000 & $20 \%$ & 9.390 .000 & Effective \\
\hline Printing Costs & 8.05 .0000 & $20 \%$ & 9.390 .000 & Effective \\
\hline Photocopy & 2.130 .500 & $5 \%$ & 2.347 .500 & Effective \\
\hline Consumption & 2.228 .000 & $5 \%$ & 2.347 .500 & Effective \\
\hline Infrastructure & 10.635 .500 & $25 \%$ & 11.737 .500 & \\
\hline Development & & & & \\
\hline
\end{tabular}

Percentage Efficiency $=\frac{41.744 .000}{46.950 .000} \times 100 \%=88.91 \%$.

Table 11. Report Recap of BOS MTs Public School 2 Semarang (In one Period)

\begin{tabular}{|l|c|c|c|c|}
\hline & Period 1 & $\begin{array}{c}\text { \% Limit } \\
\text { Use }\end{array}$ & $\begin{array}{c}\text { Limit } \\
\text { Use }\end{array}$ & \\
\hline Receipts & 48.450 .000 & & & \\
\hline Spending & & & & \\
\hline Honorarium & 4.400 .000 & $10 \%$ & 4.845 .000 & Effective \\
\hline Office Stationery & 7.055 .000 & $15 \%$ & 7.267 .500 & Effective \\
\hline Materials Display & 9.470 .000 & $20 \%$ & 9.690 .000 & Effective \\
\hline Printing Costs & 9.300 .000 & $20 \%$ & 9.690 .000 & Effective \\
\hline Photocopy & 2.386 .500 & $5 \%$ & 2.422 .500 & Effective \\
\hline Consumption & 2.393 .000 & $5 \%$ & 2.422 .500 & Effective \\
\hline Infrastructure & 12.680 .500 & $25 \%$ & 12.112 .500 & Not Effective \\
\hline Development & & & & \\
\hline
\end{tabular}


From table 10 and table 11, it can be seen that the use of BOS funds in MTs Public School in Semarang city in the Effective category. Based on the results of data analysis and discussion can be concluded that, leadership of madrasah heads affect the management of BOS funds.

\section{AUTHOR BIOGRAPHIES}

Onisimus Amtu, Assistant Professor (Lektor) at Department of Christian Religion Education, Institut Agama Kristen Negeri Ambon. He was interested in the process of education in schools after the implementation of regional autonomy in Indonesia.

Nerru Pranuta Murnaka, Expert Assistant (Asisten Ahli) at Mathematics Education Study Program STKIP Surya Tangerang. Interested in Education and Mathematics Education Management.

Nur Rohman, Expert Assistant (Asisten Ahli) at Primary Teacher Education at Islamic university of Nahdlatul Ulama Jepara.

Eni Sumarni. Teacher in Junior High School In Bengkayang. Interested in Management of Education.

\section{REFERENCES}

Depdiknas, 2006. Pemberdayaan Komite Sekolah. Dirjen Manajemen Pendidikan Dasar dan Menengah. Jakarta.

Gorton, R.A, \& Schneider, G.T. 1991. School Based Leadership, Challenges and Opportunities. Keeper Boulevard, Dubuque: Wm.C. Brown Publishers.

Mulyasa, E. 2006, Menjadi Kepala Sekolah Profesional. Bandung: Remaja Rosdakarya.

Mulyasa. 2011. Manajemen Berbasis Sekolah, Konsep, strategi dan. Implementasi. Bandung: PT Remaja Rosdakarya.

Oliver, Paul, ed. 1996. The Management of Education Change. England: Asghate Publishing Limited.

Sa'ud, S. \& Makmun A,S. 2007. Perencanaan Pendidikan, Suatu Pendekatan Komprehensif. Remaja Rosdakarya. Jakarta.

Stanbury, P. F. 2003. Principle of Fermentation Technology. Pergamon Press. Ltd. Oxford.

Undang-Undang Nomor 25 Tahun 2009 Tentang Pelayanan Publik.

Undang-Undang Republik Indonesia (RI) Nomor 20 Tahun 2003 Tentang Sistem Pendidikan Nasional.

Keputusan Menteri Pendidikan Nasional Nomor 044/U/2002 Tentang Dewan Pendidikan dan Komite Sekolah.

Keputusan Menteri Pendidikan Nasional Nomor 69 Tahun 2009 Tentang. Standar Biaya Operasi Nonpersonalia.

Peraturan Menteri Pendidikan dan Kebudayaan No. 16 Tahun 2016 Tentang Petunjuk Teknis Penggunaan Dan Pertanggungjawaban Keuangan Dana Bantuan Operasional Sekolah (BOS) . 